\title{
Projekt Federacji Europy Centralnej i Południowej w myśli politycznej emigracji polskiej w latach 1939-1943
}

Projekt Federacji Europy Centralnej i Południowej został przygotowany przez Józefa Retingera, a promowany był przez premiera rządu polskiego na uchodźstwie Władysława Sikorskiego. Zakładał współpracę polityczną, militarną, ekonomiczną przede wszystkim z Czechosłowacją, a także Jugosławią i Grecją. Przewidywał również włączenie innych państw m.in., Litwy, Węgier. Za cezurę początkową przyjęto 6 października 1939 - oficjalną wymianę depesz między Sikorskim a Benešem, będącą początkiem współpracy polsko-czechosłowackiej. Cezurę końcową stanowi śmierć naczelnego wodza polskich sił zbrojnych, która nastapiła w lipcu 1943 roku. W pracy przeanalizowano stosunek mocarstw (Wielkiej Brytanii, USA, ZSRR) do wysuniętego projektu. Wykazano również aporię wynikającą z odmiennego: polskiego i czeskiego postrzegania bezpieczeństwa w regionie, podejścia do sojuszy militarnych oraz kształtu powojennych granic.

Ułożenie dobrych relacji pomiędzy Polską a Czechosłowacją w latach 1939-1943 było niezwykle trudne. Bilateralne kontakty komplikował m.in. terytorialny spór o Zaolzie, do którego oba państwa rościły sobie prawo.

Oba kraje preferowały też odmienne kierunki polityki zagranicznej. Czechosłowacja początkowo zorientowana była przede wszystkim na przymierze z Francją i utrzymanie dobrych kontaktów ze Związkiem Radzieckim. Polska pokładała wielkie nadzieje w sojuszu z Francją, a następnie z Wielką Brytanią.

Wzajemne relacje krępowały również uprzedzenia mentalne i narodowościowe głęboko zakorzenione w obu narodach. Czesi, pacyfistyczni i zdystansowani wobec jakichkolwiek militarnych konfliktów, uznawali Polaków za naród zakompleksiony i za wszelką cenę pragnący odzyskać dawną mocarstwowość i świetność. Prezydent Czechosłowacji Edward Beneš nazywał nawet Polskę „Bałkanami środkowej Europy”, sugerując, że krewkość Polaków i ich nieprzemyślane działania mogą doprowadzić do konfliktu w tej części Europy ${ }^{1}$.

Trudne sąsiedztwo objawiało się również w przypisywanej sobie przez oba państwa roli na arenie międzynarodowej. Polska z uwagi na wielkość terytorialną i potencjał ludnościowy, a Czechosłowacja głównie za sprawą dobrze rozwiniętego przemysłu - aspirowały do przywództwa w Europie Środkowo-Wschodniej.

Stosunki dyplomatyczne charakteryzowały się podejrzliwością i nieufnością. Polski minister spraw zagranicznych Józef Beck aż do wybuchu II wojny światowej konsekwentnie realizował zdecydowanie antyczeski kierunek polityki zagranicznej. Dyplo-

\footnotetext{
1 T. Kisielewski, Federacja Środkowoeuropejska, Warszawa 1991, s. 13.
} 
maci znad Wierzbowej z kolei wyczuwali dystans, jaki przy każdej nadążającej się okazji okazywał obóz Edwarda Beneša.

Nie oznaczało to, że oba państwa nie miały wspólnych interesów. Przed wybuchem wojny obawiały się głównie Niemiec i rewizji postanowień Traktatu Wersalskiego. Korzystny grunt pod rozmowy polsko-czechosłowackie pojawił się jesienią 1939 roku, po ataku Niemiec na Polskę. Walka ze wspólnym okupantem stała się pomostem porozumienia między krajami.

W latach 1939-1943 oba państwa stały się propagatorami związku federacyjnego, który po włączeniu się m.in., Jugosławii, Grecji, Litwy miał być gwarantem pokoju, bezpieczeństwa i rozwoju ekonomicznego w Europie Środkowej i Wschodniej ${ }^{2}$. Środkowoeuropejska federacja otwarta była również na współpracę z innymi krajami, m.in., Węgrami, Rumunia, a nawet Turcją. Jej prekursorzy wiodącą rolę przypisywali porozumieniu regionalnemu, a nie ogólnoeuropejskiemu, choć nie wykluczano w dalszej perspektywie przystąpienia związku do federacji ogólnoeuropejskiej. „Po wojnie konfederacja polsko-czechosłowacka miała odegrać rolę lokalnego hegemona w Europie. Obydwa państwa były predestynowane do tej roli, ze względu na swój przyszły potencjał ludnościowy i militarny, a także tendencje antyimperialistyczne"3.

Oprócz wspomnianych kwestii spornych, najważniejszą przeszkodą na drodze do budowy federacji w Europie Centralnej i Południowej okazały się stosunki ze Związkiem Radzieckim. Od 17 września 1939 roku państwo polskie, choć oficjalnie nie wypowiedziało wojny Związkowi Radzieckiemu, de facto pozostawało z nim w stanie konfliktu. Czechosłowacja nigdy nie graniczyła z ZSRR, a po jego włączeniu się do walki z Niemcami, dążyła do oparcia bezpieczeństwa właśnie na sojuszu z Moskwą. Polska natomiast niezmiennie stała na stanowisku powrotu do granic sprzed wybuchu II wojny światowej, opartych na postanowieniach Traktatu Ryskiego z 1921 roku.

Jak się później okazało głównie za sprawą Czechosłowacji oba państwa nie potrafiły również znaleźć porozumienia w sprawie możliwości przystąpienia do federacji innych państw, m.in., Węgier i Litwy. Węgrzy pozostawali w sporze z Czechosłowacją o Ruś Zakarpacką. Natomiast sprawę przystąpienia Litwy do związku komplikował fakt, że od 1940 roku wchodziła ona w skład Związku Radzieckiego. Za włączeniem Litwy do związku przemawiały nie tylko względy strategiczne. Na jej akcesji do federacji szczególnie zależało Polakom, którzy byli z nią związani i historycznie i emocjonalnie. Czechosłowacja, nie chcąc psuć stosunków z ZSRR, pozostawała bierna wobec polskich żądań.

Jesienią 1939 roku politycy czechosłowaccy i polscy, chcąc zapewnić prawno-konstytucyjną ciągłość swoich państw dążyli do utworzenia rządów na emigracji. Uzyskali schronienie najpierw w Paryżu, a następnie w Londynie, i stamtąd prowadzili walkę $\mathrm{z}$ okupantem.

Zdając sobie sprawę z trudnych okoliczności politycznej współpracy, jeszcze przed wybuchem II wojny światowej zmianę zaistniałej sytuacji postulowały niektóre środowiska polityczne i wojskowe zarówno w Polsce, jak i w Czechosłowacji. Korzystny

\footnotetext{
2 J. Valenta, I. Stovicek, Czechoslovak-Polish negotiations..., s. 25, Praha 1995.

3 J. Juchnowski, Koncepcje federalistyczne Rowmunda Pitsudskiego, w: J. Juchnowski, J. Tomaszewski, Europa i integracja europejska w polskiej myśli politycznej XX wieku, Wrocław 2003, s. 97.
} 
grunt pod współpracę pojawił się jeszcze w latach 1932-1933, ale wtedy Edward Beneš nie był zainteresowany zacieśnieniem kontaktów z Polakami.

Ze strony polskiej promotorem współpracy z Czechosłowacją jeszcze przed wojną był generał Władysław Sikorski. Świadomy błędów polityki Józefa Becka, od wielu lat utrzymywał serdeczne kontakty z Jurajem Slavikiem, znanym czeskim polonofilem, tworząc korzystny wizerunek kontaktów polsko-czechosłowackich ${ }^{4}$.

W drugiej połowie lat trzydziestych Sikorski odbył też kilka spotkań z politykami czechosłowackimi, podczas których starał się złagodzić wzajemne negatywne nastawienie.

W 1937 roku w Pradze spotkał się z Benešem, z którym w późniejszym okresie planował utworzenie federacji polsko-czechosłowackiej. Nawiązał też życzliwe kontakty z Milanem Hodżą, ówczesnym premierem Czechosłowacji, propolsko nastawionym Słowakiem z pochodzenia. Podobnie jak w przypadku Beneša, Hodża, szczególnie w latach 1939-1941 często gościł u polskich dyplomatów, m.in., ministra Kota, z kolei znanego orędownika polsko-słowackiej współpracy.

W tym samym czasie kiedy Beneš spodziewał się ataku Niemiec, Polska zaproponowała stronie czechosłowackiej współpracę w ramach ściślejszego związku federacyjnego, który miał się stać fundamentem szerszej środkowoeuropejskiej federacji. Prezydent Czechosłowacji odmówił. W opinii Kazimierza Wierzbiańskiego, ówczesnego attaché prasowego Poselstwa RP w Pradze, czechosłowacki przywódca odmówił na skutek wyraźnego sprzeciwu Moskwy ${ }^{5}$. W tym miejscu warto nadmienić, że Czechosłowacja już od 1935 roku planowała alians ze Związkiem Radzieckim, a wstępem do współpracy był bilateralny układ z 16 maja 1935 roku.

W wyniku agresji sowieckiej 17 września 1939 roku Sikorski musiał opuścić Polskę i przeniósł się do Paryża. Podróżował przez Rumunię m.in. w towarzystwie francuskiego ambasadora Ludwika Noëla, z którym wstępnie rozmawiał na temat chęci zbliżenia stanowisk Warszawy i Pragi.

30 września 1939 roku prezydent RP na uchodźstwie mianował Sikorskiego na stanowisko premiera polskiego rządu emigracyjnego. Jego najbliższym współpracownikiem był Józef Retinger, który miał czynny udział w projektowaniu związku konfederacyjnego. We wspomnieniach Mój udziat w ruchu na rzecz jedności Europy pisał następująco: „Podczas moich częstych rozmów z generałem W. Sikorskim [...] wskazywałem na korzyści dla Polski ze sfederowania Europy oraz na niemożliwość przetrwania tak małego kraju jak Polska otoczonego przez zazdrosnych sąsiadów, nie będącego w stanie wytrzymać nacisków wywieranych przez dwa najbliżej położone mocarstwa, Rosję i Niemcy. Generał Sikorski przyjął tę ideę całkowicie i od tego czasu stał się przekonanym federalistą",

${ }^{4}$ Zob. szerzej: J. Kowalczyk, Za kulisami wydarzeń politycznych z lat 1936-1938, Warszawa 1976.

5 Zob. szerzej: Beně̌ a Polska, wywiad udzielony przez Kazimierza Wierzbiańskiego, „Zeszyty Historyczne" 1986, nr 4.

${ }^{6}$ G. Witkowski, Józef Retinger. Polski inicjator integracji europejskiej, Warszawa 2000, s. $58-59$. 
6 października 1939 roku w Paryżu pojawił się Beneš, który niezwykle aktywnie zaczął zabiegać o utworzenie emigracyjnego rządu czechosłowackiego we Francji. Obaj panowie wymienili depesze, w których wyrazili sympatię, przyjaźń i głębokie przekonanie, że oba narody - polski i czechosłowacki - wkrótce odrodzą się wolne i niepodległe ${ }^{7}$. Jeszcze w tym samym miesiącu kilka razy spotkali się. Choć nie podjęli wówczas wiążących decyzji, stworzyli dobrą atmosferę do rozmów, sugerując tym samym chęć poprawnego ułożenia bilateralnych stosunków. Podczas rozmowy Sikorski m.in. skrytykował wytyczne polityki zagranicznej Becka w latach trzydziestych.

Polski premier złożył również oficjalną wizytę w Londynie, w dniach 14-19 listopada 1939 roku, w celu podniesienia sprawy polskiej na forum międzynarodowym. Odbył szereg rozmów, m.in. z Lordem Edwardem Halifaxem, ówczesnym premierem Wielkiej Brytanii - Nevilem Chamberlainem, Lordem Chattfieldem, ministrem Koordynacji i Obrony Narodowej - Richmondem Terracem, Winstonem Churchillem - ówczesnym pierwszym Lordem Admiralicji, oraz ministrem wojny Leslie Hore Belishem ${ }^{8}$. Podczas śniadania zorganizowanego w restauracji „Savoy” przez Stowarzyszenie Prasy Zagranicznej Sikorski mówił o potrzebie konsolidacji kontynentu europejskiego 9 .

Kontakty polsko-czechosłowackie uległy chwilowemu ochłodzeniu wskutek propozycji wysuniętej przez Milana Hodżę i Stefana Osuskiego. Słowacy zaproponowali utworzenie Unii Polsko-Czesko-Słowackiej, z wyraźnym zagwarantowaniem autonomii Słowaków. W tym czasie rządu emigracyjnego Czechosłowacji jeszcze nie uznawano. Hodża i Osuski próbowali więc przeforsować swoją wizję luźniejszego związku. Byli za Czecho-Słowacją, w ramach której Czesi i Słowacy mieliby ustawowo zagwarantowane prawa. Na to nie chciał się zgodzić Beneš, który postulował powrót do granic sprzed 1938 roku, a więc centralistycznie zarządzanej Czechosłowacji.

W listopadzie 1939 roku doszło jeszcze do spotkania Edward Beneš, Milan Hodża - Władysław Sikorski, August Zaleski. Jednak o rzeczywistym zbliżeniu można było mówić na początku 1940 roku. W tym miejscu warto nadmienić, że wiele pozytywnych akcentów do współpracy wniosły spotkania ambasadora Edwarda Raczyńskiego z Edwardem Benešem, które odbyły się w grudniu 1939 roku.

18 grudnia 1939 roku premier Sikorski w odezwie do społeczeństwa polskiego mówił o potrzebie reorganizacji Europy po wojnie i stworzeniu pomiędzy Rosją a Niemcami pasa bezpieczeństwa. Jego zdaniem, bezpieczeństwo w regionie gwarantować miała właśnie federacja polsko-czechosłowacka ${ }^{10}$.

Po klęsce Francji, latem 1940 roku, rząd polski oraz wspólna reprezentacja polityków czechosłowackich musiały przeprowadzić się do Londynu ${ }^{11}$. Zwolennicy planów Beneša utworzyli Czechosłowacki Komitet Narodowy, który został uznany przez

${ }^{7}$ Monitor Polski z 16 października 1939, nr 229-231.

8 Zob. Archiwum Akt Nowych w Warszawie, Ambasada Rzeczpospolitej Polskiej w Londynie (dalej: AAN AL), sygn. 170. Program wizyty Władysława Sikorskiego i Augusta Zaleskiego w Londynie w dniach 14-19 listopada 1939 roku.

9 Zob. szerzej, Monitor Polski z 28 listopada 1939, nr 258-267.

10 Zob. szerzej, Monitor Polski z 19 grudnia 1939, nr 277-284.

11 Zob. AAN AL, sygn. 1720, Rozmowa premiera Wielkiej Brytanii Winstona Churchilla w obecności ambasadora Edwarda Raczyńskiego na temat ewakuacji wojsk polskich do Wielkiej Brytanii z dnia 19 czerwca 1940 roku. 
Wielką Brytanię i Francję w lipcu 1940 roku. W tym czasie istniała już konkurencyjna Czecho-Słowacka Rada Narodowa, w ramach której Słowacy próbowali przeforsować własną wizję współpracy państw z uwzględnieniem oddzielenia Słowaków od Czechów. Choć polski rząd na uchodźstwie utrzymywał kontakty zarówno z czeskimi, jak i słowackimi reprezentantami, z rezerwą odnosił się do wzajemnych czesko-słowackich zatargów i początkowo nie poparł żadnego z nich. Dopiero 29 lipca 1940 roku polski rząd na obczyźnie udzielił uznania emigracyjnemu rządowi czechosłowackiemu ${ }^{12}$.

Polskie Ministerstwo Spraw Zagranicznych okazywało umiarkowaną sympatię osobie Beneša. Natomiast część polskiej emigracji, szczególnie zza oceanu, zdecydowanie sprzeciwiała się zbliżeniu Polaków i Czechów. Nastawienie takie było zauważalne jesienią 1940 roku, kiedy rozmowy polsko-czechosłowackie miały wejść w zdecydowaną fazę.

Emigracyjni publicyści gazety „Ameryka echo” w następujący sposób pisali o współpracy polsko-czechosłowackiej: „Prawda, że Słowian jest więcej w Europie aniżeli narodów innych szczepów. Pamiętać jednak winniśmy, że tacy bracia-Słowianie, jak Czesi lub Ukraińcy, sprzęgali się zawsze z każdym wrogiem Słowiańszczyzny przeciw narodowi polskiemu, by nas zniszczyć. Dlatego to Polacy nie powinni bałamucić się więcej po słowiańsku. Ostrożność nie zawadzi. Pan prezydent Beneš może być wielkim mężem stanu, ale dla Polaka był i jest on wrogiem, gorszym może aniżeli wrogowie jawni i otwarci",13.

W sierpniu 1940 roku Beneš z Raczyńskim omawiali szczegóły współpracy. Wspominali o ,różnicach mentalnych pomiędzy Czechosłowakami i Polakami, a także o silnym rusofilstwie zakorzenionym u Czechów, mającym raczej charakter mistyczny niż opartym na rozumowaniu" ". Mówiono również o ścisłej współpracy w przyszłości, prowadzącej nawet do unii. Współpraca polsko-czechosłowacka miała być oparta na zasadach zupełnej równości, ze wspólną polityką zagraniczną, obronną i gospodarczą. Ważnym argumentem był postulat niemieszania się w wewnętrzne sprawy i korzystne ułożenie relacji z innymi narodami.

Jesienią 1940 roku odbyło się kilka rozmów na temat przyszłych stosunków pomiędzy Polską a Czechosłowacją. Jednym z warunków czeskich było zaniechanie rozmów polityków polskich ze słowackimi. Choć w polskim rządzie istniała silna grupa prosłowacka pod przewodnictwem ministra Kota, Beneš wymusił na Sikorskim odejście od projektowania współpracy ze Słowacją. Natomiast Hodża i Osuski ostatecznie musieli podporządkować się Benešowi.

Wiążące propozycje współpracy polsko-czechosłowackiej wysunięto w październiku 1940 roku. 17 października na obiedzie u Beneša spotkali się: Edward Raczyński, Stanisław Kot, Władysław Sikorski i Stanisław Stroński.

12 M. K. Kamiński, Rzqd RP na uchodźstwie gen. Władysława Sikorskiego wobec powołania Tymczasowego rzadu Czechostowackiego w Londynie (lipiec-wrzesień 1940), „Dzieje Najnowsze” 2005, nr 1, s. 92.

13 AAN AL, sygn. 1646, Przeglądy, wycinki prasowe z prasy polskiej i obcej (1940), notatka z 25 sierpnia 1940.

14 T. Kisielewski, Federacja Środkowoeuropejska, op. cit., s. 55. 
Spotkanie odbyło się w atmosferze kilka dni wcześniej podpisanego faszystowsko-militarystycznego sojuszu, „Paktu Trzech Mocarstw”, w skład którego wchodziły: Niemcy, Włochy, Japonia oraz Rumunia, Węgry i satelicka Słowacja ${ }^{15}$. Plany utworzenia federacji środkowoeuropejskiej miały być pierwszym krokiem do utworzenia szerszej federacji środkowoeuropejskiej i przeciwwagą wobec państw skupionych wokół Niemiec.

Podczas obiadu obie strony przystapiły do wymiany poglądów na temat warunków współpracy. Beneš zaproponował, żeby oba państwa stworzyły unię celną i uzgodniły wspólną walutę. Ponadto przewidywano utworzenie wspólnego sztabu generalnego, dowództwa oraz prowadzenie polityki zagranicznej. Uzgodniono również, że państwa posiadać będą oddzielne armie i osobne parlamenty. Beneš zaznaczył, że chciałby, aby Polska i Czechosłowacja uzgodniły wspólne stanowisko wobec ZSRR i by nie był to stosunek nieprzyjazny.

Jeszcze tego samego dnia propozycje polsko-czechosłowackie omawiano podczas popołudniowego posiedzenia Rady Ministrów RP w Londynie. Premier Władysław Sikorski zasugerował, że zapozna Radę z projektem współpracy na następnym posiedzeniu. Zwrócił uwagę, że wiele szczegółów jest jeszcze niedopracowanych. „Rozbieżności między nami a Czechami są jeszcze duże, szczególnie pod względem stosunku do Rosji. W otoczeniu Pana Beneša znajdują się ludzie o sympatiach komunizujących. Dążą oni nadal do utworzenia bezpośredniej granicy pomiędzy Czechosłowacją a Rosją"16.

Podczas posiedzenia w tej sprawie głos zabrali również ministrowie August Zaleski i Stanisław Stroński. Minister spraw zagranicznych August Zaleski podkreślił, że w rozmowie ze Zdenkiem Prohazką, chargé d'affaires przy rządzie RP na uchodźstwie, ten starał się wybadać stanowisko polskie w sprawie udziału w federacji Jugosławii i Rumunii. Minister Informacji i Dokumentacji Stanisław Stroński podkreślił, że przy budowie takiej federacji nie można zapomnieć o udziale Węgier ${ }^{17}$.

Na następnym posiedzeniu Rady Ministrów zwrócono uwagę na zainteresowanie propozycją współpracy polsko-czechosłowackiej Winstona Churchilla. Ponownie podkreślono, że mistycyzm rosyjski Czechów może początkowo stać na przeszkodzie bliższych kontaktów. Jednocześnie wyrażono głębokie przekonanie, że „pokonamy je z czasem"18.

Jeszcze tego samego dnia minister sprawiedliwości Marian Seyda przedstawił projekt deklaracji polsko-czechosłowackiej. Nadmienił, że „,celowo ograniczył mówienie o Europie Środkowo-Wschodniej, by nie myślano, że dążymy do utworzenia niepodległej Ukrainy"19.

15 H. Batowski, Z dziejów dyplomacji polskiej na obczyźnie, wrzesień 1939-lipiec 1941, Kraków-Wrocław 1984, s. 260.

16 Zob. szerzej: Protokół z posiedzenia Rady Ministrów z 17 października 1940 w Londynie, w: M. Zgórniak (red.), Protokoły z posiedzeń Rady Ministrów Rzeczpospolitej Polskiej, czerwiec 1940-czerwiec 1941, s. 146.

17 Ibidem.

18 Zob. szerzej: Protokół z posiedzenia Rady Ministrów z 29 października i 30 października 1940 w Londynie, w: Protokoty..., czerwiec 1940- czerwiec 1941, op. cit., s. 151.

19 Ibidem, s. 160. 
1 listopada minister Seyda zreferował treść opracowanego przez siebie, Zaleskiego i Strońskiego projektu wspólnej deklaracji polsko-czechosłowackiej. Po wprowadzeniu kilku poprawek, głównie przez ambasadora Raczyńskiego, projekt został uchwalony i przesłany Czechom ${ }^{20}$.

Dodatkowy asumpt do rozmów polsko-czechosłowackich dało memorandum wystosowane przez Beneša do rządu polskiego 1 listopada 1940 roku. Zwracało ono uwagę na potrzebę skonkretyzowania współpracy polsko-czechosłowackiej w ramach federacji lub konfederacji. Memorandum było punktem wyjścia dla urzeczywistnienia wzajemnej współpracy. Treść memorandum zwracała uwagę na potrzebę istnienia suwerennych państw, zachowujących odrębne rządy, parlamenty i armie. Integracja, zdaniem Beneša, miała najdalej sięgać w sprawach ekonomicznych. W memorandum duże znaczenie przypisywano porozumieniu członków federacji ze Związkiem Radzieckim.

Jeszcze przed listopadowym podpisaniem deklaracji ambasador RP w Londynie Edward Raczyński wygłosił mowę, która została opublikowana w londyńskim czasopiśmie „Czechoslovak ${ }^{21}$.

Mowa Raczyńskiego zwracała uwagę na wiele istotnych punktów polskiej polityki zagranicznej. Postulowała potrzebę istnienia związków federacyjnych lub konfederacyjnych, w których upatrywano gwarancji bezpieczeństwa w regionie. Zwracała również uwagę na potrzebę przewartościowania myślenia o suwerenności narodowej.

11 listopada 1940 roku podpisano deklarację polsko-czechosłowacką ${ }^{22}$.

Deklaracja miała być pierwszym krokiem do ściślejszej współpracy między państwami. Przewidywała odrzucenie sporów z przeszłości i utworzenie, w bliżej nieokreślonej formie, federacji środkowoeuropejskiej ${ }^{23}$.

Deklaracja miała charakter ogólnikowy, a styl wyważony. Celowo unikano sformułowania federacja lub konfederacja. W tamtym czasie dla obu krajów kwestia ustrojowa nie była najważniejsza. Ważniejszy był polityczny wydźwięk wynikający z chęci współpracy obu państw. Zgodnie z sugestią brytyjską brano pod uwagę przystapienie do związku innych krajów: Węgier, Rumunii, Grecji i Jugosławii. Polska aktywnie lobbowała na rzecz przystapienia do projektu państw bałtyckich, a w szczególności Litwy.

Po podpisaniu deklaracji zakreślono płaszczyzny współpracy, które uwidoczniły pierwsze różnice $\mathrm{w}$ podejściach obu państw. Polsce zależało na ścisłych więzach przede wszystkim politycznych, a następnie gospodarczych z Czechosłowacją. Beneš zdając sobie sprawę z większego potencjału przemysłowego Czechosłowacji, starał się przeforsować głównie współpracę ekonomiczną. To miało dać Czechom pewną przewagę polityczną. W ten sposób właśnie Czechosłowacja, a nie Polska byłaby państwem nadającym ton konfederacji ${ }^{24}$.

\footnotetext{
20 Ibidem, s. 165.

21 Artykuł Ambasadora Raczyńskiego dla pisma „Czechoslovak” przeznaczony na dzień 11 listopada, AAN AL., sygn. 1467 (bez daty).

${ }_{22}$ Zob. szerzej, Tekst deklaracji polsko-czechosłowackiej, „Dziennik Polski”, nr 106, 12 listopada 1940

${ }^{23}$ H. Batowski, W. Michowicz, A. Zamoyski, Działalność dyplomatyczna i polityczna Edwarda Raczyńskiego, Łódź 1994, s. 38.

${ }^{24}$ S. Turlej, Koncepcje ustrojowe obozu londyńskiego, Warszawa 1978, s. 223.
} 
W wypowiedziach polityków czechosłowackich przewijała się też wizja granicy czechosłowacko-radzieckiej. Ta sprawa w późniejszym czasie zaważyła na stosunkach czechosłowacko-polskich.

Tuż po podpisaniu deklaracji z 11 listopada 1940 roku, dr Zbigniew Grabowski wysłał list do ambasadora Raczyńskiego z zapytaniem o to, jak zareagować na wypowiedź Beneša opublikowaną w „Daily Telegraph”, w której ten przedstawił niekorzystne dla Polski ułożenie powojennych granic, z sugestią utworzenia granicy czechosłowacko-radzieckiej: „Proszę uprzejmie Pana ambasadora o danie mi znać, czy należałoby zareagować listem do «Daily Telegraph», chwalącym sam artykuł, ale z lekka wytykającym «niedopatrzenie» dra Beneša. Przeciwko takiego rodzaju cichej demonstracji przemawiałby fakt, że porozumienie polsko-czeskie jest tworem świeżym i delikatnym i że dlatego na terenie angielskim należałoby uniknąć za wszelką cenę sporów jakiegokolwiek rodzaju. Może to również wywołać wrażenie, że Polacy są wiecznie niezadowoleni i gotowi do podnoszenia sprzeczek z byle jakiego powodu"25.

2 grudnia 1940 roku odbyło się posiedzenie Rady Ministrów w Londynie. Podczas spotkania zwrócono uwagę głównie na odpowiedź Beneša wobec polskiej propozycji utworzenia konfederacji i na fakt, że jego propozycja kładzie nacisk na stworzenie w Europie czegoś w rodzaju miniaturowej Ligi Narodów. „Projektowana przez niego Rada Federalna, uzależniająca wszelkie decyzje od ratyfikowania ich przez parlamenty bez jakiegokolwiek czynnika odwoławczego, daleką jest od celu, do jakiego dążymy” ${ }^{26}$. Ponadto „Kładzie ona nacisk na zbliżenie ekonomiczne, co właśnie z naszej strony budzi zastrzeżenia. Daleko silniej musimy nastawić się na skonkretyzowanie współpracy w dziedzinie politycznej i wojskowej" ${ }^{27}$.

Podczas posiedzenia Rady Ministrów, 7 stycznia 1941 roku, dyrektor Adam Romer odczytał memoriał Beneša do Sikorskiego ${ }^{28}$. Strona polska zareagowała zmianą komitetów mieszanych na Komitet Organizacyjny i wyznaczeniem polskich delegatów. Czesi wysunęli Tomasa Mášaryka, Huberta Ripkę i Juraja Slavika, a Polacy do Komitetu Koordynacyjnego ministrów Augusta Zaleskiego i Kazimierza Seydę, a także ambasadora Edwarda Raczyńskiego oraz generała Kazimierza Sosnkowskiego. Ponadto do Komitetów Współpracy Bieżącej: dla spraw zagranicznych - ministra Zaleskiego i ambasadora Raczyńskiego, dla spraw wojskowych - delegata wyznaczonego przez naczelnego wodza, dla spraw propagandy - ministra Strońskiego i księdza Kaczyńskiego, dla spraw kultury i oświaty - ministrów Józefa Hallera i Stanisława Kota.

Choć strony polska i czechosłowacka wyznaczyły do współpracy swoich przedstawicieli dyplomatycznych, dopiero 14 czerwca 1941 roku ustanowiono pierwszego posła przy rządzie czechosłowackim. Był nim Kajetan Morawski ${ }^{29}$. Ze strony czeskiej funkcję tę pełnił Juraj Slavik.

25 AAN AL, sygn. 1647, Wycinki z prasy polskiej i obcej (1941), Grabowski do Raczyńskiego, list $\mathrm{z}$ dnia 11 listopada 1941.

26 Zob. szerzej: Protokół z posiedzenia Rady Ministrów z 2 grudnia 1940 w Londynie, w: Protokoty ..., t. II: czerwiec 1940-czerwiec 1941, op. cit., s.191.

27 Ibidem.

28 Zob. szerzej: Protokół z posiedzenia Rady Ministrów w Londynie z 7 i 8 stycznia 1941, w: Protokoty..., t. II: czerwiec 1940- czerwiec 1941, op. cit., s. 254-255.

29 Zob. szerzej: Sprawa obsady urzędu posła RP przy rzadzie czechosłowackim, w: H. Batowski, Z dziejów dyplomacji polskiej na obczyźnie, wrzesień 1939-lipec 1941, op. cit., s. 369-370. 
Od momentu podpisania deklaracji obaj, Sikorski i Beneš, często ze sobą korespondowali, co rychło uwidoczniło wzajemne sprzeczności w zakresie prezentowanych stanowisk $^{30}$. Niezbyt trafnie dokonali również wyboru dyplomatów do podtrzymywania wzajemnych kontaktów. Sikorski wyznaczył Augusta Zaleskiego i Edwarda Raczyńskiego, a strona czeska Huberta Ripkę.

Pomimo pojawiających się sprzeczności przy uzgadnianiu projektu związku, wyznaczone komitety pracowały aktywnie. Dochodziło do częstych spotkań. Ponadto opublikowano wiele materiałów prasowych potwierdzających wolę współpracy.

Pod koniec 1941 w pracach Komisji ds. Ekonomicznych uczestniczył m.in. znany działacz Polskiej Partii Socjalistycznej - Adam Pragier. Podczas licznych spotkań ze stroną czeską zauważył, że stosunek Czechów do projektu ustanawiającego konfederację polsko-czechosłowackąjest odmienny od naszego. Sugerował, że Czesi „,traktowali rokowania jako rzecz, od której nie wypada się uchylić, ale którą nie należy zbytnio się przejmować” ${ }^{31}$. Często unikali jednoznacznych odpowiedzi, tłumacząc się nieprzygotowaniem do podejmowanych zagadnień. Pod koniec grudnia Pragier spotkał się z Benešem, chcąc omówić szczegóły współpracy. Podczas spotkania Beneš sugerował, że tak naprawdę nie jest najważniejszy kształt konfederacji, ale sam fakt, że oba narody chcą się do siebie zbliżyć i zapomnieć o animozjach z przeszłości. Pragier zaproponował więc, aby oba rządy wystosowały pismo o uznaniu potrzeby wzajemnego zbliżenia bez żadnych konkretnych zobowiązań. Beneš wyczuł intencje Pragiera i nie chciał zdradzać prawdziwego nastawienia Czechów. Stwierdził, że jego sugestie żadnego skutku nie odniosą, a nad kształtem i formą mają pracować oba rządy. Według Pragiera „Beneš zachował się jak węgorz i to jeszcze naoliwiony” ${ }^{\text {„32. }}$

Ważnym momentem pertraktacji polsko-czechosłowackich było podpisanie 21 maja 1941 roku przez Komitet Polityczny Zasad Aktu Konstytucyjnego Związku Polski i Czechosłowacji, który regulował kompetencje wspólnie wyłonionych organów: Rady Związkowej i Prezydenta Związkowego. Proponowano otwarcie federacji na inne państwa, organizację ministerstwa spraw zagranicznych i armii oraz wspólne finanse związku.

W tym czasie obie strony: polska i czechosłowacka zostały dodatkowo zmotywowane przez prezydenta USA. Na posiedzeniu Rady Ministrów 23 maja 1941 roku premier Sikorski zdał sprawozdanie z wyjazdu do Ameryki. W obszernym wystapieniu zwrócił uwagę, że prezydent Roosevelt bardzo przychylnie odniósł się do utworzenia związku ${ }^{33}$.

Włączenie się Związku Radzieckiego do wojny w czerwcu 1941 roku miało decydujący wpływ na kształtowanie się stosunków polsko-czechosłowackich. ZSRR stał się teraz partnerem koalicji antyhitlerowskiej. W obliczu wspólnego wroga pojawiła

30 Zob. szerzej: S. Stanisławska, Projekty konfederacji polsko-czechosłowackiej w czasie II wojny światowej, „Sprawy Międzynarodowe” 1963, nr 4.

31 A. Pragier, Czas przeszły dokonany, Londyn 1966, s. 623.

32 Ibidem, s. 625.

33 Zob. szerzej, Protokół z posiedzenia Rady Ministrów w Londynie z 23 maja 1941, w: Protokoty..., t. II: czerwiec 1940-czerwiec 1941, op. cit., s. 358. 
się możliwość nawiązania stosunków z Moskwą i uregulowania spraw granicy wschodniej.

Latem 1941 roku odbyło się kilka rozmów polsko-radzieckich, dotyczących m.in. zwolnienia polskich więźniów aresztowanych po wkroczeniu Armii Czerwonej do Polski w 1939 roku oraz tworzenia polskich legionów w ZSRR.

Poważnym krokiem organizacyjnym, który sugerował rychłe zacieśnienie relacji polsko-czechosłowackich i skonkretyzowanie działań, było podjęcie przez Radę Ministrów 19 września 1941 roku „Uchwały w sprawie składu delegacji polskich do mieszanych komitetów polsko-czechosłowackich".

Na mocy tej decyzji utworzono 9 komitetów, m.in., polityczno-prawny (stronę polską reprezentował Edward Raczyński, stronę czechosłowacką Jan Mášaryk), gospodarczo-finansowy (Henryk Strasburger, Eduard Utrata) ${ }^{34}$.

27 października 1941 roku na kolejnym posiedzeniu Rady Ministrów ambasador Raczyński zreferował „Tezy konstytucyjne Związku Polski i Czechosłowacji”, opracowane przez MSZ na podstawie uchwalonego przez Komitet Polityczny Ministrów „Projektu Zasad Aktu Konstytucyjnego Związku Polski i Czechosłowacji”. Podczas spotkania zwrócono uwagę na szereg kwestii koniecznych do uzgodnienia w przyszłości. Dr Leon Grossfeld zwrócił uwagę na pewne niejasności pod względem kompetencji związkowych ministra spraw zagranicznych zaznaczył też, że „minister Mikołajczyk podkreślił konieczność uzyskania szerszych postulatów w dziedzinie politycznej i wojskowej" "35. Ostatecznie Rada Ministrów z małymi poprawkami przyjęła tezy konstytucyjne Związku Federacyjnego Państw Polskiego i Czechosłowackiego.

Na przełomie grudnia 1941 i stycznia 1942 roku rząd czechosłowacki przedstawił rządowi polskiemu dokument „Podstawowe Zasady Konfederacyjnego Związku Czechosłowacji i Polski”. Resztą prac zajął się Komitet Koordynacyjny, którego działanie wydatnie przyczyniło się do wypracowania aktu konfederacji.

Rozmowom polsko-czechosłowackim towarzyszyło wstępne nawiązanie kontaktów polsko-radzieckich. W połowie grudnia 1941 roku generał Sikorski złożył oficjalną wizytę na Kremlu. Podpisał deklarację o współpracy z ZSRR, jednak nie wspomniano tam o próbie stworzenia związku federacyjnego polsko-czechosłowackiego.

15 stycznia 1942 roku Jugosławia i Grecja podpisały porozumienie o utworzeniu Unii Bałkańskiej. Akt ten sprzyjał konsultacjom polsko-czechosłowackim. Pojawiła się możliwość utworzenia bloku federacyjnego sięgającego od Morza Egejskiego do Morza Bałtyckiego. Kilka dni wcześniej, 11 stycznia, Sikorski rozpoczął również negocjacje w sprawie przystapienia do związku Litwy. 23 stycznia 1942 roku podpisano projekt konfederacji polsko-czechosłowackiej. Związek miał być wstępem do szerszej współpracy europejskiej, która przewidywała m.in. ,istnienie wspólnej polityki zagranicznej, przy zachowaniu własnych służb zagranicznych i dyplomatycznych, wspólnej

\footnotetext{
34 Zob. szerzej: Protokół z posiedzenia Rady Ministrów z 19 września 1941, w: Protokoły..., t. III: czerwiec 1941-grudzień 1941, op. cit., s. 192-197.

35 Zob. szerzej: Protokół z posiedzenia Rady Ministrów z 19 września 1941, w: Protokoły..., t. III: czerwiec 1941-grudzień 1941, op. cit., s. 242-243.
} 
polityki wojskowej i obronnej, przy zachowaniu własnych armii, walutowej, przy zachowaniu własnych walut, oraz handlowej i gospodarczej"36.

Treść deklaracji była wyraźnym ukłonem w stronę Czechosłowacji, która nie chcąc narażać się Związkowi Radzieckiemu, niejednoznacznie odnosiła się do dyskutowanych w trakcie pracy nad projektem możliwości współpracy w ramach konfederacji z innymi państwami, szczególnie z wchodzącymi w skład Związku Radzieckiego państwami bałtyckimi.

W styczniu 1942 roku w Nowym Jorku, z inicjatywy Polski, Czechosłowacji, Jugosławii i Grecji powołano również ,The Central and East European Planning Board"37, w celu określenia powojennego porządku w Europie i uściślenia zakresu kooperacji państw. Od tego momentu bezpieczeństwo tej części Europy gwarantować miał związek federacyjny (pas bezpieczeństwa) złożony z czterech państw. W dniach 24-25 kwietnia 1942 roku powołano Institut on Educational Reconstruction Central Eastern Europe (Instytut Rekonstrukcji Europy Centralnej Środkowej i Wschodniej). Rozpoczęto agitację wśród zainteresowanych państw i przystąpiono do organizacji konferencji poświęconych reorganizacji Europy Centralnej Środowej i Wschodniej po wojnie $^{38}$. Ważnym aspektem działalności była edukacja demokratyczna społeczeństw ${ }^{39}$.

Na łamach polskiej prasy emigracyjnej pojawiły się liczne opinie na temat podpisanego 23 stycznia projektu konfederacyjnego. Nowojorski „Robotnik” poddał ocenie deklarację Polski i Czechosłowacji. Autor artykułu, Aleksander Herz, nadmienił, iż w samym sygnowaniu projektu nadzwyczaj ważne było to, ,że deklaracja nie zamyka drogi do wstapienia do związku przed innymi narodami [...] dlatego mamy prawo widzieć w deklaracji londyńskiej nadzwyczaj pozytywny krok w kierunku wygrania pokoju opartego na nowym porządku politycznym świata"40.

Podczas kolejnego pobytu Sikorskiego w USA, prezydent Roosevelt przychylnie odniósł się do pomysłu polsko-czechosłowackiego. Jednocześnie zdradzał obawy związane z powstaniem związku mniejszych państw bez uczestnictwa w tym mocarstw zachodnich. Ponadto Amerykanie uważali, że układ ten może uderzać w Związek Radziecki, a tego nie chcieli.

36 J. Szkolarski, Epilog układu Sikorski-Beně̌. Z dziejów polsko-czechosłowackich 1939-1949, Łódź 1988, s. 319-320; zob. szeroko, AAN AL, sygn. 1763, Odpis protokołu dotyczącego utworzenia konfederacji Polski i Czechosłowacji z dnia 23 stycznia 1942.

37 Wymieniany w poniższym artykule Grzegorz Witkowski, autor książki Józef Retinger - polski propagator integracji europejskiej, podaje, że nazwa tej instytucji jest nieprzethumaczalna na język polski. Kazimierz Łastawski podaje nazwę Rada Planowania Europy Środkowo-Wschodniej. Por. K. Łastawski, Od idei do integracji europejskiej, Warszawa 2004, s. 98.

38 E. Crozier, Polish-Czech-Grek-Yugioslaw federation maybe the answer, „New York Herald Tribune", June 201943.

39 Zob. AAN, AL, sygn. 1609 (Rekonstrukcja Europy po wojnie), odpowiedź Tomasa Mášaryka na propozycję udziału w sesji Instytutu Edukacji Rekonstrukcji Europy w Nowym Jorku, kwiecień 1942; AAN, AL, sygn. 1609, Wypowiedź generała Sikorskiego na temat propozycji udziału w sesji Instytutu Edukacji Rekonstrukcji Europy w Nowym Jorku. Dokument z 16 grudnia 1942 roku; AAN, AL, sygn. 1609, Wypowiedź Savy Kosanovica z 7 kwietnia 1943 r., podczas otwarcia sesji Instytutu Edukacji Rekonstrukcji Europy Centralnej i Wschodniej; AAN, AL, sygn. 1609, Wypowiedź Feliksa Grossa, sekretarza generalnego Komitetu, podczas spotkania w dniach 7-8 kwietnia 1943 roku.

40 AAN AL, sygn. 1653, Przegląd prasy polskiej na emigracji (1940, 1942), A. Herz (bez tytułu), „Robotnik Polski”, nr 8, Nowy Jork 1942. 
Im bliżej obie strony starały się współpracować, tym większe rysowały się różnice poglądów. Polska chciała niezmiennie powrotu do granic sprzed 1939 roku, a Czechosłowacja żądała powrotu do status quo sprzed spotkania monachijskiego, co wyraziła w deklaracji uchwalonej przez Radę Państwa w maju 1942 roku. Ponadto, zacieśniając coraz bardziej kontakty ze Związkiem Radzieckim, żądała od Polski przyjaznego ustosunkowania się do ZSRR. Kolejną kwestią sporną była wspomniana propozycja Polski przyłączenia do związku najpierw Litwy i innych państw bałtyckich, a następnie Węgier. Czechosłowacja, nie ukrywając swoich rusofilskich upodobań, odrzucała tę propozycję. Węgry natomiast były w konflikcie granicznym z Czechosłowacją od końca 1938 roku.

25 marca 1942 roku, podczas pobytu w USA, Sikorski spotkał się m.in., z podsekretarzem stanu USA Sumnerem Wellsem. Polski premier przedstawił wytyczne polskiej polityki zagranicznej. Stwierdził, że w powojennym układzie Polska zmierza do stworzenia w Europie ustroju federacyjnego na obszarze pomiędzy Bałtykiem a Morzem Czarnym, Egejskim i Adriatykiem. Zwrócił też uwagę, że Związek Radziecki krytycznie odnosi się do tego pomysłu, co jego zdaniem zdradza imperialne zapatrywania Moskwy. Podsekretarz Stanu USA odniósł się entuzjastycznie do propozycji Sikorskiego ${ }^{41}$.

27 kwietnia Sikorski w towarzystwie Józefa Retingera spotkał się z Winstonem Churchillem, sir Stafordem Crippsem oraz Duncanem Sandysem. Poruszyli m.in., sprawę utworzenia po wojnie w Europie związków federacyjnych. Zarówno Churchill, jak i Cripps bardzo przychylnie zapatrywali się na tę wizję. Zapytali wprost Sikorskiego, czy drażliwe sprawy pomiędzy stronami zostały już załatwione. Sikorski odpowiedział, że „sprawę cieszyńską” już załatwiono. Sikorski zwrócił również uwagę, że jest konieczne, ,aby Czesi tym razem uniknęli błędu sprzed 25 lat i liczyli się bardziej z sąsiadem, z którym mają wspólne granice z wyroku Opatrzności, niż Rosją, która im imponuje wielkością, ale która nie była, nie jest i nie będzie ich sąsiadem",42.

W maju 1942 roku doszło do spotkania pomiędzy Sikorskim a Benešem. Spotkanie przebiegało w chłodnej atmosferze. Premier Polski zarzucał czeskiemu prezydentowi, że jego stosunek do Związku Radzieckiego cechuje uległość i brak neutralności w stosunku do sprawy polskiej. Beneš oświadczył, że „Czechosłowacja może się nawet obejść bez konfederacji z Polską̧" ${ }^{33}$. Już wcześniej, w marcu 1942 roku, po przyjeździe z USA Sikorski zauważył, że należy mieć baczną uwagę na postępowanie Beneša. Twierdził, że prowadzi nieczystą grę: „raz odskakuje od Polski, a drugi raz grzeje się przy ogniu Stalina,44.

W opinii bliskiego współpracownika i wieloletniego sekretarza Józefa Retingera Jana Pomiana rozmowom polsko-czechosłowackim nie sprzyjał również temperament

41 Por. Sprawozdanie z rozmowy generała Władysława Sikorskiego z podsekretarzem stanu Sumnerem Wellsem w dniu 25 marca 1942, w: M. Zgórniak (red.), Protokoły..., t. IV: grudzień 1941-sierpień 1942, op. cit., s. 229-230.

42 Por. Sprawozdanie z rozmowy Sikorskiego z Churchillem, Dandysem, Cripssem z 27 kwietnia 1942, w: Protokoty..., t. IV: grudzień 1941-sierpień 1942, op. cit., s. 268-275.

${ }^{43}$ T. Kisielewski, Federacja Środkowoeuropejska, op. cit., s. 187.

44 Por. Stenogram posiedzenia Rady Narodowej z 22 kwietnia 1942, w: E. Duraczyński, R. Turkowski, O Polsce na uchodźstwie, Rada Narodowa RP na uchodźstwie, Warszawa 1997, s. 109. 
przywódców obu państw: ,,ani Beneš, ani Sikorski nie czuli do siebie sympatii. Nie było prawie wypadku, by ich rozmowy kończyły się bez kwasów"45.

Sikorski nie ufał Benešowi, a mając wybuchowy temperament denerwował się często z różnych powodów. Wydaje się, że charakter Sikorskiego trafnie uchwycił Jan Rostworowski, pisząc w swojej książce, że problem jego polegał na tym, iż był jednocześnie naczelnym wodzem i premierem. ,Gdy tylko wyczuwał jakieś trudności, przypominał sobie, że jest generałem, zapominał o polityce"46.

Od lata 1942 roku Związek Radziecki toczył z Niemcami zacięte walki na froncie południowym. W tym czasie wizja konfederacji polsko-czechosłowackiej coraz bardziej się oddalała. Świadczy o tym wypowiedź Beneša, który w tym czasie został odpowiednio poinstruowany przez rosnący w siłę militarnie i politycznie ZSRR. „Aczkolwiek idea konfederacji mniejszych państw Europy Środkowej została przyjęta od samego początku prawie z powszechnym uznaniem, jako podstawa przyszłego pokoju w powojennej Europie, jednakże niejasna sytuacja w Europie Środkowej nie pozwala rządowi czechosłowackiemu na przyjęcie zobowiązań i powzięcie ostatecznych decyzji przed upływem wojny [...]. Zresztą rząd czechosłowacki nie mógłby powziąć żadnych decyzji co do konfederacji z Polską, względnie co do szerszego porozumienia środkowoeuropejskiego, bez uprzedniej zgody niektórych wielkich mocarstw"47.

3 czerwca 1942 roku zebrał się po raz szósty i ostatni Komitet Koordynacyjny polsko-czechosłowacki. Podczas spotkania doszło do ostrej wymiany zdań pomiędzy jej uczestnikami. Strona polska zarzucała stronie czechosłowackiej, że ta w deklaracji Rady Państwa z 18 maja poruszała sprawy granicy polsko-czechosłowackiej, choć wcześniej obiecywała, że sprawą tą zajmą się na sam koniec rokowań ${ }^{48}$.

Czechosłowacja coraz bardziej dystansowała się od współpracy z Polską. Nieoficjalnie Beneš wycofywał się z wcześniejszych decyzji dotyczących utworzenia konfederacji. Sugerował, że w przyszłości, po wojnie powstanie wiele problemów w stosunkach z Rumunią, Węgrami, Austrią. Natomiast polsko-czechosłowackie i jugosłowiańsko-greckie układy traktował raczej jako akty woli, a nie propozycje współpracy ${ }^{49}$.

W lipcu 1942 roku Sikorski wysłał list do Beneša. Zwrócił w nim uwagę na nikłe wyniki wspólnych działań, przekreślonych głównie obustronnym szowinizmem i przykuwaniem bacznej uwagi do reminiscencji historycznych. Smutnie skonstatował, że

45 J. Pomian, Życie i pamiętniki ,szarej eminencji”, Warszawa 1990, s. 126.

46 K. Niesnaski, Pamiętniki Ciechanowskiego, „Wiadomości” 1947, nr 19.

47 W. T. Kowalski, Walka dyplomatyczna o miejsce Polski w Europie, Warszawa 1979, s. 68.

48 Na spotkaniu byli obecni: Mikołajczyk, Raczyński, Stroński, Strasburger, Seyda, Popiel, Kwapiński, Kulski i Tarnowski. Polska reprezentacja wystapiła przeciwko rezolucjom czeskiej Rady Państwa. „Polscy członkowie Komitetu Koordynacyjnego zwracają uwagę członkom czechosłowackim na rezolucję Rady Państwowej z 18 maja, w której sprzecznie z wspólnymi uchwałami, mówi się o kwestii granic polsko-czechosłowackich, a sprzecznie z wspólnymi oświadczeniami polsko-czechosłowackimi z dnia 11 listopada 1940 oraz z dnia 19 stycznia 1942 r., jest podkopywana zasada ściślejszej konfederacji polsko-czechosłowackiej, i oczekują w tej sprawie wyjaśnień czechosłowackich członków Komitetu Koordynacyjnego". Zob. szerzej: M. Zgórniak, Protokół z posiedzenia Rady Ministrów z 6 czerwca 1942, w: Protokoły..., t. IV: grudzień 1941-sierpień 1942, op. cit., s. 326-334.

49 T. Kisielewski, Federacja Środkowoeuropejska, op. cit., s. 205. 
„waga sporów polsko-czechosłowackich wydaje mu się odwrotnie proporcjonalna do ścisłości i znaczenia związku, jaki w przyszłości zaistnieje pomiędzy obu krajami" ${ }^{, 50}$.

Przed kolejnym wyjazdem Sikorskiego do Stanów Zjednoczonych doszło do spotkania: Sikorskiego, Raczyńskiego, Ripki, Mášaryka i Beneša. Polski premier zakładał, że przedstawi Rooseveltowi postępy realizacji polsko-czechosłowackich planów. Nie podjęto jednak żadnych wiążących decyzji. Kolejną debatę zaplanowano na czas po powrocie Sikorskiego z USA.

W 1943 roku trwał impas w kontaktach polsko-czechosłowackich. Świadczy o tym wypowiedź Sikorskiego, który po powrocie ze Stanów Zjednoczonych w Radzie Narodowej przedstawił sprawozdanie i stosunek amerykański do wspólnych polsko-czechosłowackich planów. Na pytanie zgromadzonych co do przyszłości związku polsko-czechosłowackiego i amerykańskich planów na ten temat odpowiedział, że „Benešowi to się zupełnie w głowie pomieszało" ${ }^{\text {, }}$.

2 lutego 1943 premier Sikorski na tajnym posiedzeniu Rady Ministrów referował stan zaawansowania polsko-czechosłowackich planów. Mówił o propozycjach przedstawionych Amerykanom. Oprócz wcześniej wymienionych, zwrócił również uwagę na: konieczność współpracy ze Związkiem Radzieckim w ramach federacji, oswobodzenie Węgier i Rumunii z elementów faszystowskich, zrzeczenie się suwerenności narodowej, ale tylko na rzecz nadrzędnej organizacji, lecz nigdy na rzecz obcego mocarstwa $^{52}$.

Zwycięstwo ZSRR pod Stalingradem wywarło poważny wpływ na polsko-czechosłowackie konsultacje. Wobec braku osiagnięcia porozumienia, 17 maja 1943 roku strona czechosłowacka zaproponowała tymczasowe zawieszenie negocjacji i rozmów. De facto był to koniec marzeń o stworzeniu konfederacji polsko-czechosłowackiej.

25 maja 1943 roku na posiedzeniu Rady Narodowej Czechosłowacji miało miejsce wystąpienie Edwarda Raczyńskiego na temat stosunków polsko-czechosłowackich. W obszernym wystąpieniu Raczyński - jeszcze w tonie największej dyplomacji-zdradzał szereg obaw co do dalszej współpracy, szczególnie po oświadczeniu ministra Ripki, że wspólne plany konfederacyjne zostają zawieszone: „17 maja 1943 roku podczas narady państwowej polsko-czechosłowackiej minister Ripka oświadczył, że plany stworzenia konfederacji polsko-czechosłowackiej zostają tymczasowo zawieszone. Biorąc pod uwagę moje exposé wygłoszone 4 kwietnia tego roku w Komitecie Rady Ministrów, nie mogę zrozumieć intencji i powodów, dla których Pan Ripka złożył takie nieoczekiwane oświadczenie dla sprawy, którą jeszcze niedawno oba kraje uznały za najważniejsza, a sam Pan Ripka uznał za nadrzędny cel polityki zagranicznej swego kraju. Niemniej wprowadził on wielki zamęt do głównego tematu rozmów pomiędzy stronami jak dotąd zgodnych. Chciałbym przypomnieć o „gentlemans agreement”, jaką uznały oba kraje w 1940 roku, i dodać kilka słów na temat aktualnej sytuacji.

50 Por. Sikorski do Beneša, lipiec 1942, w: Protokoły..., t. IV: grudzień 1941-sierpień 1942, op. cit., s. 377-383.

${ }_{51}$ E. Duraczyński, R. Turkowski, O Polsce na uchodźstwie, op. cit., s.131.

52 Zob. szerzej: Wypowiedź premiera Władysława Sikorskiego podczas tajnego posiedzenia Rady Ministrów w dniu 2 lutego 1943, w: Protokoły..., t. IV: grudzień 1941-sierpień 1942, op. cit., s. $345-347$. 
Pierwszą sprawą jest przystapienie Związku Radzieckiego do wojny przeciw Niemcom w 1941 roku. Fakt ten nie przeszkodził współpracy i kształtowaniu dobrych relacji pomiędzy Polską a Czechosłowacją, jednakże utwierdził nas w przekonaniu, że Polska nie może narzucać Czechosłowacji opinii co do kształtowania relacji pomiędzy zainteresowanymi krajami. Polska zachowała życzliwą powściągliwość w stosunku do pojawiających się problemów w relacjach Czechosłowacji z innymi sąsiadami z centralnej Europy i sposobów ich rozwiązania. Z drugiej strony głęboko wierzyła, że problemy te, a w szczególności ich propozycje rozwiązania, będą rozwiązane w sposób przyjacielski, poza tym problemy te mogłyby zbliżyć oba kraje [...]. Atak Niemiec na Związek Radziecki nie tylko wymusił walkę na dwa fronty, co w moim przekonaniu przyczyni się do rychłego końca wojny. Wydawało się, że walka przeciwko wspólnemu wrogowi stworzy korzystny grunt pod ułożenie wzajemnych politycznych relacji. Jednakże okazuje się, że dawne problemy i tarcia utrzymują się i będą utrzymywać się w przyszłości. Związek Radziecki i prowadzona przez niego polityka zburzyła grunt, który razem stworzyliśmy i na którym chcieliśmy stworzyć federację. A przecież plany konfederacyjne nie wynikają z antyradzieckich uprzedzeń. Pokojowy charakter współpracy polsko-czechosłowackiej powinien leżeć w interesie Związku Radzieckiego. Konfederacja ma zagwarantować pokój w regionie i dlatego pomysł spotkał się z dużą przychylnością na całym świecie. I dlatego też polski rząd dalej będzie starał się stworzyć unię państw w środkowowschodniej Europie. Polski rząd prowadzi politykę otwartą i zachęca inne kraje regionu do współpracy i wstępowania w szeregi unii. Tylko w ten sposób w przyszłości uda się zachować pokój w Europie i storpedować zamiary Niemiec. Wierzymy, że nasze dążenia będą odpowiednio zrozumiane i podtrzymane przez Wielką Brytanię, odpowiedzialnego partnera i która jak do tej pory była konfederacji zwolennikiem. Wierzymy również, że w takim kształcie poprą naszą propozycję Stany Zjednoczone. Jesteśmy pewni, że korespondencyjnie interesy w stworzeniu konfederacji ma również Francja. Wierzymy w końcu, że Związek Radziecki doceni wagę przedsięwzięcia i weźmie pod uwagę jego pozytywne strony i zażąda jego realizacji. [...] Różnice zdań i problemy, jakie pojawiły się podczas spotkań strony czeskiej i polskiej $\mathrm{z}$ reguły prowadziły do pozytywnych rozwiązań. Konieczne jest, aby pojawiające się różnice zdań nie przeszkodziły w dalszej dyskusji nad projektem konfederacji [...]. Główne punkty współpracy zostały określone w deklaracji z listopada 1941 roku oraz dodatkowym protokole z 19 stycznia 1942 roku. Jest mi niezwykle przykro to powiedzieć, ale wypowiedź Pana Ripki bardzo nas rozczarowuje. Wierze jednak, że porozumienie pomiędzy dwoma krajami będzie możliwe, gdyż w moim przekonaniu wymuszają je okoliczności historyczne"53.

Zbliżeniu polsko-czechosłowackiemu nie pomogła również Wielka Brytania, która coraz bardziej dystansowała się od sporu polsko-sowieckiego. Churchill widział w Związku Radzieckim silnego sojusznika i nie chciał drażnić Stalina zdecydowanym poparciem dla Polski. „Londyn wspierał ideę unii środkowoeuropejskiej, ale równocześnie nie miał zamiaru wspierać Polaków w ich dążeniach do odzyskania ziem wschodnich przedwojennego państwa polskiego. Już od jesieni 1939 roku dawał Ro-

53 AAN AL, sygn. 1493, Odpis przemówienia Edwarda Raczyńskiego podczas zebrania Rady Narodowej Czechosłowacji w Londynie z 25 maja 1943. 
sjanom do zrozumienia, że zaakceptowałby jej terytorialne zdobycze, w tym i dokonane na Polsce, byle tylko ZSRR oderwał się od Niemiec" ${ }^{\text {54 }}$.

1 czerwca 1943 roku Józef Zarański - II radca ambasady RP w Londynie - spotkał się z F. A. Voigtem, brytyjskim pisarzem i dziennikarzem. Odbył z nim rozmowę na temat stosunków polsko-czechosłowackich. Podczas rozmowy Voigt stał na stanowisku, że pozycja Polski w regionie wzmocniłaby się, gdyby ta zrzekła się Zaolzia i tym samym uznała status quo sprzed Monachium. Zarański odpowiedział, że Polska się na to nie zgodzi: „Odpowiedziałem mu, że dla Polski obowiązujący jest status quo sprzed 1 września 1939 roku, którego narażenie w stosunku do jednego sąsiada podważałoby ten status quo wobec innych" ${ }^{5}$. Zarański kontynuował: „Voigt wysuwał argumenty na poparcie swoich tez. Replikował, że uznanie przez Polskę granic przedmonachijskich w Europie wzmocniłoby naszą pozycję w stosunku do terytorialnych pretensji sowieckich, gdyż wojna zaczęła się od Monachium"s6. W związku z tą uwagą podniosłem, że Voigt idzie dalej niż prezydent Beneš, który w mowie wygłoszonej ostatnio w senacie amerykańskim powiedział, że wojna rozpoczęła się okupacją Pragi, 15 marca 1939 roku" $^{, 57}$. Voigt wypowiedział się również negatywnie na temat projektów poddania sprawy Zaolzia arbitrażowi i uznał ten fakt za niebezpieczny dla nas precedens w stosunku do granicy polsko-sowieckiej. Na koniec listu Zarański stwierdził, że wręczył Voigtowi tekst oświadczenia ministra Raczyńskiego, wygłoszonego w Radzie Narodowej Czechosłowacji, w którym ten choć powściaggliwie, wykazywał fałszywą grę czeską.

19 sierpnia 1943 roku Władysław Kulski odbył rozmowę z prezydentem Benešem na temat współpracy polsko-czechosłowackiej. Przesłał odnośne sprawozdanie do MSZ, z którego wynikało, że Czechosłowacja nie jest zainteresowana współpracą polsko-czechosłowacką, a politykę bezpieczeństwa będzie opierać o sojusz z ZSRR ${ }^{58}$.

Choć Beneš starał się jeszcze zmodyfikować projekt w taki sposób, żeby poparł go ZSRR, Kreml po zerwaniu stosunków dyplomatycznych z Polską, wiosną 1943 roku w ogóle nie brał tego pod uwage $e^{59}$.

Próby utworzenia związku federacyjnego w Europie Centralnej i Południowej, którego trzonem miała być współpraca polsko-czechosłowacka zakończyły się fiaskiem. Choć oficjalnie mocarstwa koalicji antyhitlerowskiej odnosiły się do pomysłu przychylnie, partykularne interesy poszczególnych państw ostatecznie wzięły górę ${ }^{60}$. Nie

54 T. Kisielewski, Polski punkt widzenia w stosunkach polsko-czechostowackich w okresie II wojny światowej, „Dzieje Najnowsze” 2000, nr 3, s. 139.

55 AAN AL, sygn. 1493 (pismo tajne), Józef Zarański do ministra J. Morawskiego, list z 5 czerwca 1943.

56 Ibidem.

57 Ibidem.

58 AAN AL, sygn. 1493, Władysław Kulski do Foreign Office (pismo poufne), relacja ze spotkania z prezydentem, Benem, list z 9 września 1943.

59 J. Nemé́ek, Edward Beneš i Władysław Sikorski, spojrzenie ze strony czeskiej, „Dzieje Najnowsze" 2000, nr 3, s.132.

60 Por. AAN, AL, sygn. 1609, Obszerny raport Feliksa Grossa - ,Activity of the Central and Eastern European Planning Board", obejmujący okres od 15 stycznia 1942 do 15 kwietnia 1943 roku, zawierający m.in. amerykańskie opnie na temat roli Instytucji, charakterystykę najważniejszych Komitetów, m.in. edukacyjnych, ekonomicznych, oraz perspektywy współpracy ze Stanami Zjednoczonymi, kwiecień 1943. 
doszli również do porozumienia inni potencjalni członkowie federacji: Jugosłowianie i Grecy.

Tuż przed śmiercią Sikorski próbował bezskutecznie interweniować w Stanach Zjednoczonych. Jednak w tym czasie Roosevelt stał na stanowisku, aby nie izolować Związku Radzieckiego od spraw europejskich i niechętnie odnosił się do planów federacyjnych państw środkowoeuropejskich wymierzonych właśnie przeciwko Związkowi Radzieckiemu. Tym bardziej, że ZSRR od lata 1943 roku przejął inicjatywę na froncie wschodnim, co było kluczową sprawą dla zwycięstwa nad hitlerowskimi Niemcami.

Udział Kremla w koalicji antyhitlerowskiej osłabił też dążenia federacyjne Brytyjczyków $^{61}$. Churchill nie chciał narażać się Stalinowi, wynik końcowy wojny był ważniejszy od żądań pojedynczego sojusznika.

Choć narody Europy Zachodniej i Ameryki witały projekt konfederacji jako cenny dorobek doświadczenia dziejowego narodów sąsiadujących z Niemcami, nie doszło do porozumienia. ,Te same narody sąsiadowały z drugiej strony z Rosją, a gdy ona weszła w krąg Narodów Zjednoczonych, okazało się, że ma inne zamiary w sprawie Europy Środkowo-Wschodniej. Czesi skręcili na pięcie, bez pożegnania, jakby nigdy umów nie podpisali" "62.

Po śmierci Sikorskiego w lipcu 1943 roku fotel premiera RP na uchodźstwie objął Stanisław Mikołajczyk. Choć starał się porozumieć z Czechami, a nawet pojechał do Moskwy, by porozmawiać ze Stalinem o przyszłości współpracy regionu, nie spotkał się z życzliwą postawą Stalina wobec Polski. ZSRR miał już swój plan integracji Europy Centralnej i Południowej, ale pod swoim przewodnictwem.

W grudniu 1943 roku ze Związku Radzieckiego wrócili Beneš i Mášaryk. Opromienieni osobowością Stalina, podpisali porozumienie o współpracy ze Związkiem Radzieckim. Już wtedy stali na stanowisku zerwania toczonych dyskusji na temat utworzenia federacji. Beneš tłumaczył Stalinowi, że rozmowy z Polakami odbywały się poza jego plecami i tylko pod presją Brytyjczyków, od których był całkowicie zależny. Ujemnie oceniał wszystkich prawie polskich polityków, względnie przychylnie wypowiadał się tylko o Mikołajczyku i ludowcach, z którymi można będzie ewentualnie w przyszłości kooperować, w ramach wspólnego układu polsko-czechosłowacko-sowieckiego" ${ }^{\text {63 }}$.

Aż do momentu włączenia się Związku Radzieckiego do wojny przeciwko Niemcom plany utworzenia konfederacji polsko-czechosłowackiej rozwijały się pomyślnie. Choć wiele spraw dzieliło oba państwa, politycy utrzymywali ścisłe kontakty i próbowali osiagnąć trudny consensus. W momencie zacieśnienia się kontaktów radziecko-czechosłowackich wspólne plany okazały się niemożliwe. Rozmowy przedłużały się, głównie przez podejrzliwość i ostrożność Czechów.

Związek Radziecki nie chciał zgodzić się na istnienie związku wymierzonego przeciwko niemu i stopniowo wymuszał na Czechosłowacji odejście od wspólnych

61 E. Duraczyński, ZSRR wobec projektów konfederacji polsko-czechosłowackiej 1940-1943, „Dzieje Najnowsze” 1997, s. 133-134.

62 S. Stroński, Związi państw, „Wiadomości”, nr 10, 9 czerwca 1946.

63 Protokoly..., t. VI, lipiec 1943-kwiecień 1944, s. 23. 
z Polakami planów. Czechosłowacja natomiast całkowicie opierała swoją politykę zagraniczną właśnie na sojuszu z Moskwą. Oprócz sporów wokół Zaolzia była to główna przyczyna niepowodzenia planów Sikorskiego i Beneša. Obie strony dzieliła również sprawa przystąpienia do związku innych państw, w szczególności Węgier, Litwy. Choć wydawało się, że postulat zacieśnienia wzajemnych kontaktów pomiędzy Czechosłowacją a Polską był racjonalnie argumentowany, nie doszło do stworzenia konfederacji. Okazało się, że oba państwa mają odmienną wizję zagwarantowania bezpieczeństwa $\mathrm{w}$ regionie. 